\title{
COEXISTING BIOTITES AND HORNBLENDES FROM SOME GRANITIC ROCKS IN SOUTHERN KITAKAMI MOUNTAINS, JAPAN
}

\author{
SaTOSHI KanisaWA \\ Department of Earth Science, College of Arts and Sciences, Tohoku \\ University, Sendai
}

\begin{abstract}
Coexisting biotites and hornblendes in granitic rocks from the Kitakami mountains were chemically analyzed. Most of biotites have composition near the phlogopite-annite series. Hornblendes of the Hitokabe, Tono and Kesengawa masses are similar in composition one another, but those of the Hirota mass are poorer in $\mathrm{Al}$ and $\mathrm{Na}+\mathrm{K}$ and richer in $\mathrm{Si}$ than those of the former three masses. The $\mathrm{Mg}-\mathrm{Fe}^{+2}$ distribution coefficients for coexisting biotite-hornblende pairs from the Hitokabe, Tono, Kesengawa and Hirota masses are $0.79,0.69,0.70$ and 0.67 , respectively. These differences depend largely upon $\mathrm{Al}$ contents in these minerals.
\end{abstract}

\section{INTRODUCTION}

Recently, Onuki (1969) has summarized geologic features of the Kitakami mountains, and Katada et al. (1971) proposed zonal arrangement of the Cretaceous granitic rocks of the district on the basis of field occurrence, petrography and petrochemistry.

In the Kitakami mountains, large amounts of sedimentary and effusive rocks belonging to the Paleozoic and the Mesozoic in age are exposed, and are intruded by many kinds of plutonic rocks. Almost all granitic rocks of the district belong to the late Mesozoic and their K-Ar ages are 105129 m.y., according to Kawano and Ueda (1965). These Cretaceous granitic rocks of the district have following peculiar characteristics among the Japanese granitic rocks. They have scarcely suffered crustal move- ments after their intrusion, and they have not been covered so widely by the younger sediments, thus their original features and rock facies at the period of intrusion might have been almost maintained. Moreover, these granitic rocks form many bodies of various sizes, comprising various rock facies.

In the present paper, the chemical features of biotites and hornblendes from granitic rocks in the southern part of the Kitakami mountains are described.

The author is indebted to Professor Kenzo Yagi of the Hokkaido University for critical reading of the manuscript and helpful suggestion.

\section{Petrography of Rocks}

Biotites and hornblendes were separated and chemically analyzed from four independent granitic masses; the Hitokabe, 
the Tono, the Kesengawa and the Hirota masses. The Hitokabe mass consists of typical hornblende-biotite granodiorite and hornblende-biotite-quartz diorite and their data were already presented (Kanisawa, 1969). The Tono mass is composed of biotite granodiorite, biotite-hornblende granodiorite and hornblende-biotite-quartz diorite, sometimes containing clinopyroxene. The Kesengawa mass is composed of biotite-hornblende granodiorite and biotite-hornblendequartz diorite, sometimes containing clinopyroxene, and contain abundant dark inclusions of various size. The Hirota mass consists of clinopyroxene-biotite-hornblende granodiorite. From the facts that the effect of contact metamorphism is limited in narrow part, rock facies is fine to medium grained and massive, and optical properties of plagioclases scatter in wider range than those of the other masses (Kanisawa, 1972), the Hirota mass may represent a shallow intrusive body.

Distribution of granitic rocks and locations of the analyzed samples are shown in Fig. 1.

Chemical analyses of granitic rocks containing analyzed minerals are given in

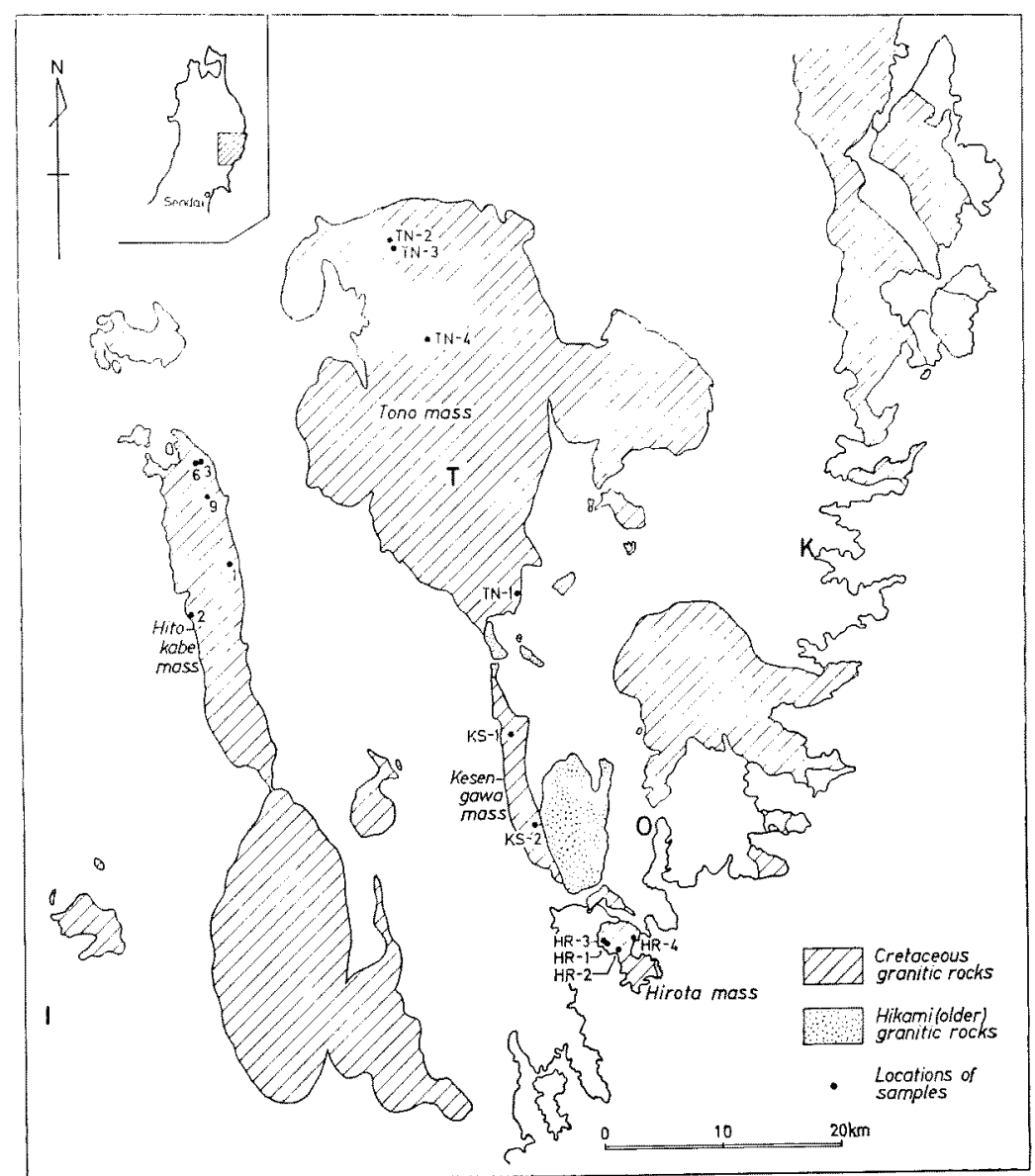

Fig. 1. Distribution of granitic rocks of the Kitakami mountains, with locations of the analyzed samples, I; Ichinoseki, T; Tono, O; Ofunato, K; Kamaishi. 
Table 1. From these data, granitic rocks of the district show the trend of typical calcalkaline rock series. No distinct differences in chemical composition are recognized among these granitic masses, though the Hirota mass is slightly richer in $\mathrm{K}_{2} \mathrm{O}$ than in others. Thus, normative Q-Or- $(\mathrm{Ab}+\mathrm{An})$ diagram shows that all analyzed rocks fall

Table 1. Chemical analyses and norms of some analysed hornblende and biotite bearing granitic rocks.

\begin{tabular}{|c|c|c|c|c|c|c|c|c|c|c|}
\hline & \multicolumn{4}{|c|}{ Tono } & \multicolumn{2}{|c|}{ Kesengawa } & \multicolumn{4}{|c|}{ Hirota } \\
\hline & $\mathrm{TN}-\mathrm{I}$ & TN-2 & $\mathrm{TN}-3$ & $\mathrm{TN}-4$ & $\mathrm{KS}-1$ & $\mathrm{KS}-2$ & HR-1 & HR-2 & HR-3 & $\mathrm{HR}-4$ \\
\hline $\mathrm{SiO}_{2}$ & 56.52 & 62.34 & 67.01 & 70.35 & 57.11 & 64.97 & 60.60 & 61.56 & 62.77 & 62.53 \\
\hline $\mathrm{TiO}_{2}$ & 1.11 & 0.58 & 0.41 & 0.25 & 0.90 & 0.59 & 0.73 & 0.71 & 0.67 & 0.68 \\
\hline $\mathrm{Al}_{2} \mathrm{O}_{3}$ & 17.71 & 16.74 & 15.17 & 15.54 & 17.54 & 15.33 & 15.62 & 15.74 & 15.09 & 16.17 \\
\hline $\mathrm{Fe}_{2} \mathrm{O}_{3}$ & 1.84 & 2.46 & 2.22 & 1.99 & 3.17 & 2.32 & 2.62 & 2.44 & 2.32 & 2.07 \\
\hline $\mathrm{FeO}$ & 5.48 & 3.14 & 2.29 & 0.90 & 4.41 & 2.78 & 4.18 & 3.89 & 3.62 & 3.22 \\
\hline $\mathrm{MnO}$ & 0.13 & 0.09 & 0.07 & 0.06 & 0.11 & 0.09 & 0.11 & 0.10 & 0.10 & 0.12 \\
\hline $\mathrm{MgO}$ & 3.92 & 2.73 & 1.79 & 0.76 & 3.25 & 1.99 & 3.03 & 2.87 & 2.67 & 2.13 \\
\hline $\mathrm{CaO}$ & 7.09 & 5.65 & 3.91 & 3.23 & 6.52 & 4.31 & 5.72 & 5.75 & 5.08 & 4.87 \\
\hline $\mathrm{Na}_{2} \mathrm{O}$ & 3.25 & 3.19 & 3.37 & 4.85 & 3.64 & 3.40 & 3.10 & 2.78 & 2.83 & 3.58 \\
\hline $\mathrm{K}_{2} \mathrm{O}$ & 1.86 & 1.63 & 2.70 & 1.73 & 2.40 & 3.21 & 3.17 & 3.33 & 3.62 & 3.15 \\
\hline $\mathrm{H}_{2} \mathrm{O}_{+}$ & 0.98 & 0.71 & 0.63 & 0.43 & 1.05 & 1.14 & 0.79 & 0.71 & 0.67 & 0.85 \\
\hline $\mathrm{H}_{2} \mathrm{O}_{-}$ & 0.05 & 0.04 & 0.04 & 0.04 & 0.04 & 0.07 & 0.05 & 0.01 & 0.03 & 0.20 \\
\hline $\mathrm{P}_{2} \mathrm{O}$ & 0.22 & 0.14 & 0.16 & 0.08 & 0.23 & 0.16 & 0.17 & 0.18 & 0.16 & 0.24 \\
\hline Total & 100.16 & 99.44 & 99.77 & 100.21 & 100.37 & 100.36 & 99.89 & 100.07 & 99.63 & 99.81 \\
\hline$Q$ & 8.13 & 20.57 & 25.67 & 27.75 & 8.08 & 20.81 & 13.28 & 16.15 & 17.71 & 16.08 \\
\hline C & - & - & - & 0.01 & - & - & - & - & - & - \\
\hline for & 11.01 & 9.62 & 15.96 & 10.23 & 14.18 & 18.96 & 18.74 & 19.68 & 21.41 & 18.63 \\
\hline$F\{a b$ & 27.46 & 26.99 & 28.51 & 40.98 & 30.76 & 28.72 & 26.20 & 23.48 & 23.89 & 30.23 \\
\hline an & 28.13 & 26.49 & 18.24 & 15.48 & 24.41 & 17.07 & 19.29 & 20.60 & 17.74 & 18.71 \\
\hline wo & 2.37 & 0.27 & 0.07 & - & 2.70 & 1.38 & 3.33 & 2.82 & 2.70 & 1.64 \\
\hline Di en & 1.33 & 0.17 & 0.05 & - & 1.68 & 0.87 & 1.98 & 1.69 & 1.63 & 0.96 \\
\hline is & 0.94 & 0.08 & 0.01 & - & 0.86 & 0.42 & 1.17 & 0.98 & 0.92 & 0.59 \\
\hline Hy $\left\{\begin{array}{l}\text { en } \\
\text { n }\end{array}\right.$ & 8.47 & 6.66 & 4.43 & 1.90 & 6.45 & 4.11 & 5.60 & 5.49 & 5.05 & 4.37 \\
\hline${ }^{\text {Hy }}$ Ifs & 5.99 & 2.85 & 1.81 & - & 3.33 & 1.95 & 3.33 & 3.14 & 2.88 & 2.71 \\
\hline Mt & 2.67 & 3.57 & 3.22 & 2.37 & 4.59 & 3.36 & 3.80 & 3.55 & 3.36 & 2.99 \\
\hline Il & 2.11 & 1.11 & 0.78 & 0.47 & 1.72 & 1.12 & 1.38 & 1.35 & 1.28 & 1.29 \\
\hline $\mathrm{Hm}$ & - & - & - & 0.35 & 一 & - & - & - & - & - \\
\hline Ap & 0.50 & 0.34 & 0.37 & 0.20 & 0.54 & 0.37 & 0.40 & 0.44 & 0.37 & 0.57 \\
\hline D.I. & 46.60 & 57.18 & 70.14 & 78.96 & 53.02 & 68.49 & 58.22 & 59.31 & 63.01 & 64.94 \\
\hline $\mathrm{Mg} / \mathrm{Mg}+\mathrm{Fe}^{+2}+\mathrm{Mn}$ & 0.58 & 0.66 & 0.64 & 0.59 & 0.61 & 0.63 & 0.65 & 0.63 & 0.63 & 0.62 \\
\hline
\end{tabular}

TN-1. Clinopyroxene bearing hornblende-biotite-quartz diorite.

TN-2. Hornblende-biotite granodiorite.

TN-3. Hornblende-biotite granodiorite.

TN-4. Biotite granodiorite.

KS-1. Hornblende-biotite-quartz diorite.

KS-2. Clinopyroxene bearing hornblende-biotite granodiorite.

HR-1. HR-4. Clinopyroxene-hornblende-biotite granodiorite.

Analyst: S. Kanisawa 


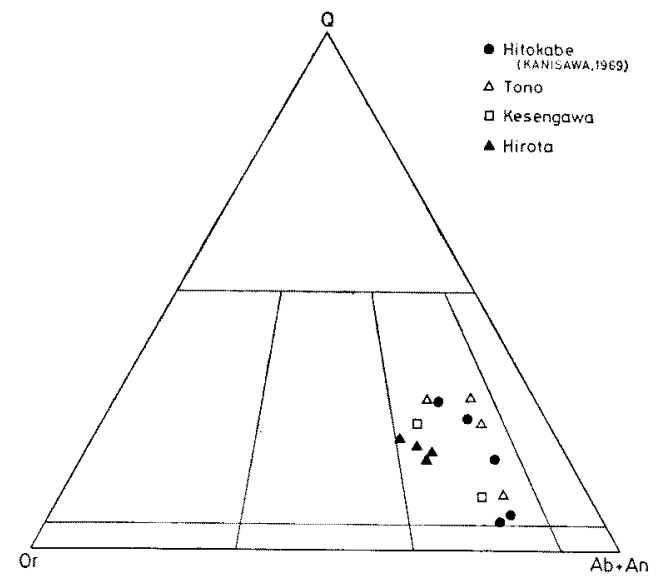

Fig. 2, Normative $Q-O r-(A b+A n)$ diagram of host rocks containing the analyzed minerals. The same symbols are used in all figures.

within the granodiorite field (Fig. 2).

\section{OGGURRENGES OF BIOTITE AND HORNBLENDE}

Biotites are generally anhedral and show pleochroism with $\mathrm{X}=$ pale yellow and $\mathrm{Z}=$ brown to light brown. Those of the Hirota mass are somewhat reddish brown. Sometimes biotites are altered to chlorite and sphene. Apatite, zircon and iron ore are common inclusions. Biotites from the Hirota mass are often rimmed with small needle crystals of iron ore.

Hornblendes are generally subhedral prismatic crystals and green to browhish green in $Z$-axial colour. Simple twinning on (100) is common. Sometimes, hornblendes from the Tono mass show weak zonal structure having brownish core and greenish rim. Inclusions of plagioclase and biotite are common, and rarely clinopyroxene occurs as core of hornblende. Rocks of the Hirota mass always contain clinopyroxene core having $\mathrm{b}=\mathrm{Y}$ and $\mathrm{c}$-axis in common with the associated hornblende, which may have been produced by reaction of granitic magma with pre-existing clinopyroxene during crystallization. Frequently, hornblendes of the Hirota mass have irregular actinolitic part showing $2 \mathrm{Vx}=73-75^{\circ}, \mathrm{c} \wedge Z=16^{\circ}$, and very weak pleochroism. Apatite and iron ore are common inclusions in hornblendes of all the masses. Usually, biotite and hornblende are closely associated with sharp boundary, both as inclusions and contiguous grains, but they do not show any reaction relation with each other. Though the sequence of crystallization is uncertain, they may have crystallized almost simultaneously, or biotite may have been slightly later than hornblende. In all analyzed rocks, K-feldspar and magnetite coexist with biotite and hornblende.

\section{Chemigal Gomposition of Mine-} RALS

In total ten specimens of biotite and nine of hornblende were separated from the host rocks and chemically analysed. These biotites and hornblendes are all coexisting pairs except one biotite (TN-4) of the Tono mass which is not associated with hornblende. All analyses were made by the conventional wet method, the alkalies being determined by means of atomic absorption spectroscopy, and $\mathrm{TiO}_{2}$ and $\mathrm{MnO}$ by colorimetry. Chemical composition and structural formulae of analysed minerals are given in Tables 2 and 3. The data of the Hitokabe granodioritic mass of the district (Kanisawa, 1969 ) is included here for discussion. Structural formulae were calculated on the basis of $24(\mathrm{O}, \mathrm{OH})$ from the analytical data.

Biotites are all well within trioctahedral biotite field defined by Deer et al. (1963b). Their $\mathrm{SiO}_{2}$ content is within $36.4-38.8 \%$ and other components also vary only in very narrow ranges. Their main variations in- 
Table 2. Chemical analyses of biotites from some granitic rocks, Kitakami Mountains.

\begin{tabular}{|c|c|c|c|c|c|c|c|c|c|c|}
\hline & \multicolumn{4}{|c|}{ Tono } & \multicolumn{2}{|c|}{ Kesengawa } & \multicolumn{4}{|c|}{ Hirota } \\
\hline & $\mathrm{TN}-1$ & TN-2 & TN-3 & $\mathrm{TN}-4$ & $\mathrm{KS}-1$ & $\mathrm{KS}-2$ & HR-1 & HR-2 & HR-3 & HR-4 \\
\hline $\mathrm{SiO}_{2}$ & 38.84 & 36.44 & 36.42 & 36.40 & 36.63 & 36.55 & 37.61 & 38.09 & 37.40 & 36.97 \\
\hline $\mathrm{TiO}_{2}$ & 3.16 & 3.70 & 3.34 & 3.94 & 3.79 & 3.86 & 4.33 & 4.35 & 4.70 & 5.02 \\
\hline $\mathrm{Al}_{2} \mathrm{O}_{3}$ & 13.49 & 14.00 & 14.69 & 14.88 & 14.24 & 13.85 & 13.19 & 12.63 & 12.64 & 12.98 \\
\hline $\mathrm{Fe}_{2} \mathrm{O}_{3}$ & 2.19 & 3.52 & 3.17 & 3.91 & 2.77 & 3.84 & 2.27 & 3.64 & 2.44 & 1.04 \\
\hline $\mathrm{FeO}$ & 18.11 & 16.32 & 16.29 & 12.98 & 17.51 & 15.95 & 16.68 & 16.50 & 17.48 & 17.91 \\
\hline $\mathrm{MnO}$ & 0.27 & 0.27 & 0.40 & 0.85 & 0.33 & 0.45 & 0.31 & 0.25 & 0.28 & 0.34 \\
\hline $\mathrm{MgO}$ & 9.78 & 11.88 & 11.85 & 13.50 & 10.80 & 11.22 & 11.82 & 10.62 & 11.32 & 12.15 \\
\hline $\mathrm{CaO}$ & 1.75 & 0.31 & 0.45 & 0.24 & 1.37 & 1.51 & 1.34 & 1.39 & 1.13 & 0.63 \\
\hline $\mathrm{Na} 2 \mathrm{O}$ & 0.35 & 0.27 & 0.37 & 0.22 & 0.33 & 0.33 & 0.36 & 0.72 & 0.36 & 0.31 \\
\hline $\mathrm{K}_{2} \mathrm{O}$ & 7.78 & 8.57 & 8.74 & 8.46 & 8.18 & 7.60 & 8.25 & 8.18 & 8.44 & 8.66 \\
\hline $\mathrm{H}_{2} \mathrm{O}_{+}$ & 3.90 & 4.18 & 3.13 & 4.08 & 3.39 & 4.10 & 3.71 & 2.85 & 3.41 & 3.44 \\
\hline $\mathrm{H}_{2} \mathrm{O}$ & 0.02 & 0.02 & 0.03 & 0.11 & 0.10 & 0.11 & 0.14 & 0.10 & 0.17 & 0.04 \\
\hline Total & 99.64 & 99.48 & 99.87 & 99.57 & 99.44 & 99.37 & 100.01 & 99.32 & 99.77 & 99.49 \\
\hline \multicolumn{11}{|c|}{ Numbers of ions on the basis of $24(\mathrm{O}, \mathrm{OH})$} \\
\hline Si & 5.867 & 5.509 & 5.607 & 5.439 & 5.616 & 5.530 & 5.682 & 5.864 & 5.717 & 5.653 \\
\hline $\mathrm{Al}^{\mathrm{lV}}$ & 2.133 & 2.491 & 2.393 & 2.561 & 2.384 & 2.466 & 2.318 & 2.136 & 2.273 & 2.336 \\
\hline $\mathrm{Al}^{\mathrm{V}}{ }^{1}$ & 0.265 & $-\cdots$ & 0.268 & 0.055 & 0.184 & - & 0.026 & 0.151 & - & - \\
\hline $\mathrm{Ti}$ & 0.358 & 0.420 & 0.386 & 0.442 & 0.435 & 0.438 & 0.490 & 0.503 & 0.539 & 0.576 \\
\hline $\mathrm{Fe}^{+3}$ & 0.248 & 0.399 & 0.366 & 0.437 & 0.318 & 0.436 & 0.257 & 0.421 & 0.281 & 0.119 \\
\hline $\mathrm{Fe}^{+2}$ & 2.280 & 2.056 & 2.090 & 1.615 & 2.237 & 2.011 & 2.100 & 2.117 & 2.227 & 2.282 \\
\hline $\mathrm{Mn}_{\mathrm{n}}$ & 0.034 & 0.034 & 0.052 & 0.108 & 0.042 & 0.057 & 0.040 & 0.032 & 0.036 & 0.044 \\
\hline $\mathrm{Mg}$ & 2.216 & 2.694 & 2.737 & 3.026 & 2.484 & 2.546 & 2.679 & 2.453 & 2.596 & 2.787 \\
\hline $\mathrm{Ca}$ & 0.283 & 0.050 & 0.074 & 0.039 & 0.225 & 0.245 & 0.217 & 0.229 & 0.185 & 0.103 \\
\hline $\mathrm{Na}$ & 0.102 & 0.080 & 0.111 & 0.063 & 0.098 & 0.096 & 0.105 & 0.214 & 0.106 & 0.092 \\
\hline $\mathrm{K}$ & 1.501 & 1.654 & 1.718 & 1.614 & 1.600 & 1.469 & 1.592 & 1.607 & 1.647 & 1.690 \\
\hline $\mathrm{OH}$ & 3.929 & 4.212 & 3.213 & 4.065 & 3.464 & 4.136 & 3.737 & 2.925 & 3.474 & 3.506 \\
\hline $\mathrm{Mg} / \mathrm{Mg}+\mathrm{Fe}^{+2}+\mathrm{Mn}$ & 0.489 & 0.563 & 0.561 & 0.637 & 0.522 & 0.552 & 0.556 & 0.533 & 0.534 & 0.545 \\
\hline
\end{tabular}

Analyst: S. Kanisawa

clude differences in contents of $\mathrm{Mg}^{+2}, \mathrm{Fe}^{+2}$, $\mathrm{Mn}^{+2}$ and $\mathrm{Ti}^{+4}$, and differences in the amount of $\mathrm{Al}$ in tetrahedral co-ordination. $\mathrm{Mg} /$ $\mathrm{Fe}$ ratios of biotites in the Tono mass tend to increase with increasing differentiation index (D.I.) of the host rocks, and similar tendency is shown in the Kesengawa mass. $\mathrm{Al}_{2} \mathrm{O}_{3}$ content ranges from 13 to $15 \%$ in the Tono, Kesengawa and Hitokabe masses, but that in the Hirota mass is somewhat lower, being about $12 \%$, whereas $\mathrm{TiO}_{2}$ content of biotites in the Hirota mass is higher than that of the other masses. From the com- parison of the structural formulae, biotites of the Hirota mass have no or little octahedral Al. According to Nockolds (1947), biotites associated with pyroxenes in calcalkaline igneous rocks are poor in $\mathrm{Al}$ and rich in $\mathrm{Ti}$, thus octahedral sites in biotite are frequently occupied by Ti. Biotites in the Hirota mass are always associated with clinopyroxene and poor in $\mathrm{Al}$ and rich in $\mathrm{Ti}$, thus their chemical characteristics agree with Nockolds' opinion. Similar biotites rich in $\mathrm{Ti}$ and poor in $\mathrm{Al}$ occur in the Orikabe granodiorite mass in the Kitakami moun- 
Table 3. Chemical analyses of hornblendes from some granitic rocks, Kitakami Mountains.

\begin{tabular}{|c|c|c|c|c|c|c|c|c|c|}
\hline & \multicolumn{3}{|c|}{ Tono } & \multicolumn{2}{|c|}{ Kesengawa } & \multicolumn{4}{|c|}{ Hirota } \\
\hline & TN-1 & TN-2 & $\mathrm{TN}-3$ & $\mathrm{KS}-1$ & $\mathrm{KS}-2$ & HR-1 & HR-2 & HR-3 & HR-4 \\
\hline $\mathrm{SiO}_{2}$ & 46.76 & 46.54 & 46.23 & 45.61 & 46.10 & 47.97 & 47.86 & 48.10 & 48.79 \\
\hline $\mathrm{TiO}_{2}$ & 1.23 & 1.59 & 1.45 & 1.66 & 1.57 & 1.13 & 1.25 & 1.13 & 1.22 \\
\hline $\mathrm{Al}_{2} \mathrm{O}_{3}$ & 7.26 & 6.96 & 8.66 & 8.18 & 7.48 & 4.78 & 5.33 & 5.75 & 4.14 \\
\hline $\mathrm{Fe}_{2} \mathrm{O}_{3}$ & 3.82 & 4.73 & 3.61 & 4.00 & 4.88 & 4.35 & 3.94 & 3.31 & 3.49 \\
\hline $\mathrm{FeO}$ & 14.00 & 11.63 & 11.96 & 12.84 & 11.95 & 11.96 & 12.55 & 13.07 & 13.57 \\
\hline $\mathrm{MnO}$ & 0.38 & 0.45 & 0.52 & 0.43 & 0.60 & 0.51 & 0.50 & 0.49 & 0.68 \\
\hline $\mathrm{MgO}$ & 10.90 & 11.63 & 12.14 & 11.49 & 11.76 & 12.78 & 12.56 & 12.71 & 12.83 \\
\hline $\mathrm{CaO}$ & 12.35 & 12.82 & 11.63 & 11.83 & 11.75 & 13.22 & 12.23 & 11.71 & 11.35 \\
\hline $\mathrm{Na}_{2} \mathrm{O}$ & 1.10 & 1.35 & 1.36 & 1.21 & 1.38 & 1.10 & 1.19 & 1.16 & 1.12 \\
\hline $\mathrm{K}_{2} \mathrm{O}$ & 0.82 & 0.68 & 0.76 & 0.85 & 0.87 & 0.60 & 0.72 & 0.67 & 0.58 \\
\hline $\mathrm{H}_{2} \mathrm{O}_{+}$ & 1.91 & 2.06 & 1.81 & 1.99 & 1.99 & 1.87 & 1.92 & 2.17 & 2.17 \\
\hline $\mathrm{H}_{2} \mathrm{O}$ & 0.02 & 0.00 & 0.04 & 0.00 & 0.07 & 0.06 & 0.04 & 0.09 & 0.05 \\
\hline Total & 100.40 & 100.55 & 100.17 & 100.09 & 100.40 & 100.33 & 100.09 & 100.36 & 99.99 \\
\hline \multicolumn{10}{|c|}{ Numbers of ions on the basis of $24(\mathrm{O}, \mathrm{OH})$} \\
\hline $\mathrm{Si}$ & 6.927 & 6.830 & 6.811 & 6.757 & 6.810 & 7.090 & 7.079 & 7.062 & 7.200 \\
\hline $\mathrm{Al}^{\mathrm{IV}}$ & 1.073 & 1.117 & 1.189 & 1.243 & 1.190 & 0.832 & 0.921 & 0.938 & 0.719 \\
\hline $\mathrm{Al}^{\mathrm{VI}}$ & 0.193 & 0.084 & 0.312 & 0.183 & 0.109 & - & 0.007 & 0.056 & - \\
\hline $\mathrm{Ti}$ & 0.137 & 0.175 & 0.160 & 0.185 & 0.174 & 0.125 & 0.138 & 0.124 & 0.135 \\
\hline $\mathrm{Fe}^{+3}$ & 0.425 & 0.521 & 0.400 & 0.444 & 0.541 & 0.482 & 0.437 & 0.365 & 0.386 \\
\hline $\mathrm{Fe}^{+2}$ & 1.728 & 1.422 & 1.468 & 1.585 & 1.471 & 1.473 & 1.547 & 1.599 & 1.669 \\
\hline $\mathrm{Mn}$ & 0.048 & 0.055 & 0.065 & 0.054 & 0.075 & 0.064 & 0.062 & 0.061 & 0.085 \\
\hline $\mathrm{Mg}$ & 2.422 & 2.822 & 2.683 & 2.557 & 2.606 & 2.833 & 2.786 & 2.799 & 2.840 \\
\hline $\mathrm{Ca}$ & 1.960 & 1.845 & 1.836 & 1.877 & 1.860 & 2.094 & 1.938 & 1.842 & 1.795 \\
\hline $\mathrm{Na}$ & 0.315 & 0.384 & 0.387 & 0.347 & 0.395 & 0.314 & 0.341 & 0.329 & 0.321 \\
\hline $\mathrm{K}$ & 0.155 & 0.127 & 0.143 & 0.160 & 0.165 & 0.114 & 0.137 & 0.125 & 0.110 \\
\hline $\mathrm{OH}$ & 1.886 & 2.014 & 1.779 & 1.966 & 1.961 & 1.843 & 1.894 & 2.125 & 2.136 \\
\hline $\mathrm{Mg} / \mathrm{Mg}+\mathrm{Fe}^{+2}+\mathrm{Mn}$ & 0.577 & 0.656 & 0.636 & 0.609 & 0.628 & 0.648 & 0.634 & 0.628 & 0.618 \\
\hline
\end{tabular}

Analyst: S. Kanisawa

tains (Kato, 1972). Biotites having no octahedral aluminum in the Tono and Kesengawa masses contain $\mathrm{OH}$ exceeding 4.1. The amounts of $\left(\mathrm{Fe}^{+2}+\mathrm{Mg}\right)$ are almost constant (4.5-4.8), thus $\mathrm{Fe}^{+2}$ and $\mathrm{Mg}$ are mutually compensative. The value of $\mathrm{Ti}+$ $\left.\mathrm{Fe}^{+3}+\mathrm{Al}^{\mathrm{IV}}\right)$ is approximately 1 , and $\mathrm{Si}$ ranges from 5.43 to 5.86 , thus the compositions of biotites are plotted near the phlogopite-annite series in the diagram of Deer et al. (1963b) (Fig. 3). With increasing differentiation index of the host rocks, the amount of $\mathrm{Si}$ in the biotite decreases (Fig. 4), thus the composition of biotites change toward siderophyllite-eastonite series as shown in Fig. 3.

The compositions of hornblendes is also not so variable, but those of the Hirota mass are richer in $\mathrm{SiO}_{2}$ and poorer in $\mathrm{Al}_{2} \mathrm{O}_{3}$ and $\mathrm{TiO}_{2}$ than those of the other masses. According to Leake's classification (Leake, 1968), all hornblendes from the Hitokabe mass fall within ferro-hornblende field, while those from other masses within magnesiohornblende field. In hornblendes from the Tono and Kesengawa masses, the $\mathrm{Mg} / \mathrm{Fe}$ 


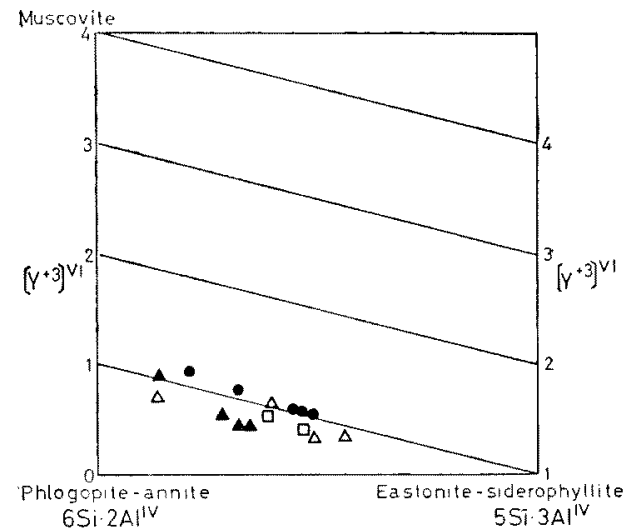

Fig. 3. Variation diagram of biotites after Deer et al. (1963b).

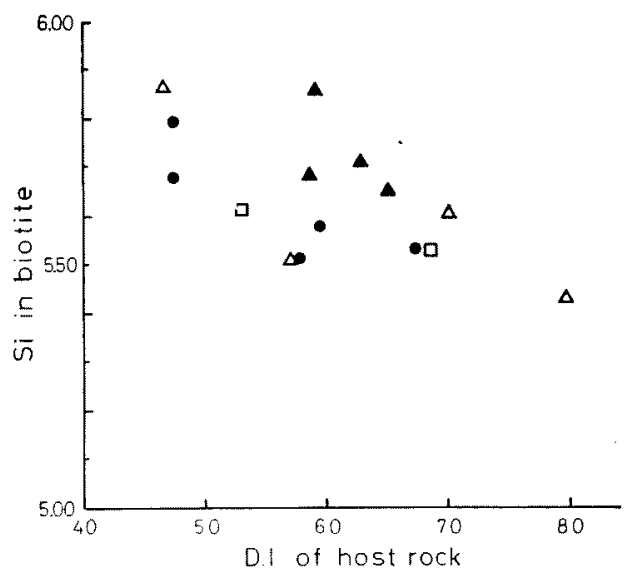

Fig. 4. Relationship between $\mathrm{Si}$ content in biotites and the differentiation index of the host rocks.

ratio tend to increase with increasing D.I. of the host rocks as in the case with the biotites. From structural formulae and the atomic ratios plotted on the diagram of Deer et al., (1963a), it is evident that hornblendes of the Hitokabe, Tono and Kesengawa masses are similar in composition to one another, while those of the Hirota mass are poorer in $\mathrm{Al}^{\mathrm{IV}}, \mathrm{Na}+\mathrm{K}$, and $\mathrm{Al}^{\mathrm{VI}}+\mathrm{Ti}+\mathrm{Fe}^{+3}$ and richer in Si than those of the other masses (Fig. 5). Tetrahedral Al substituting $\mathrm{Si}$ is more than one atom per unit formula in
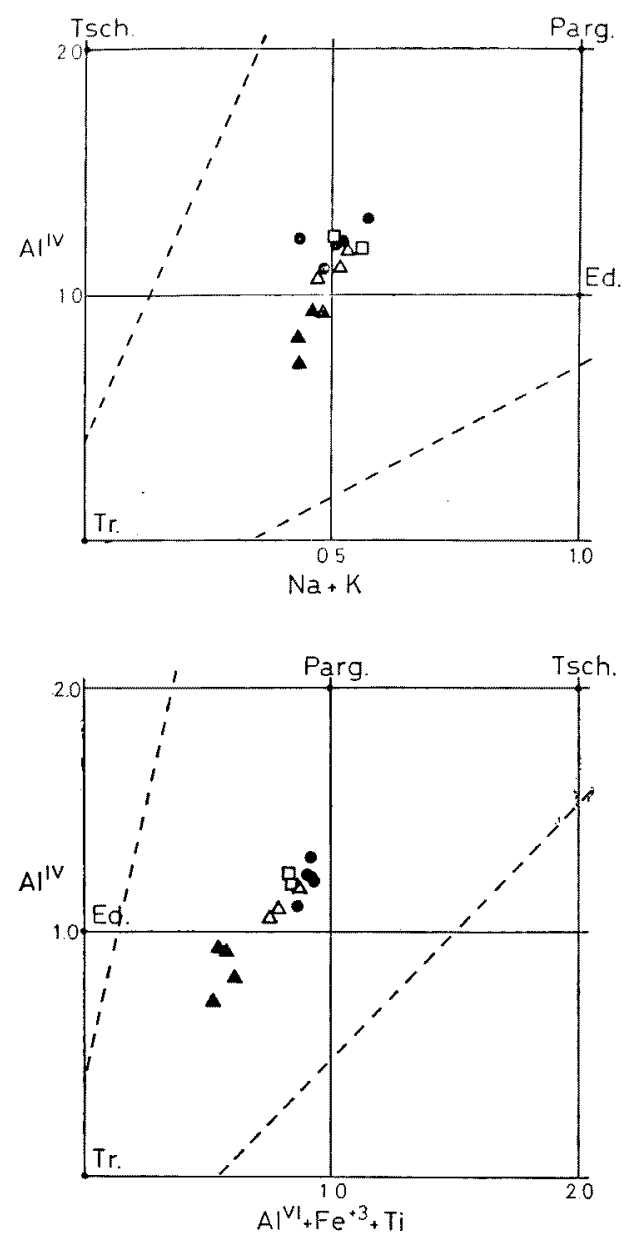

Fig. 5. $\mathrm{Al}^{1 \mathrm{v}}-\mathrm{Na}+\mathrm{K}$ diagram and $\mathrm{Al}^{1 \mathrm{~V}}-\mathrm{Al}^{\mathrm{VI}}$ $+\mathrm{Fe}^{+\mathbf{a}}+\mathrm{Ti}$ diagram of hornblendes after Deer et al. (1963a).

hornblendes from the Tono, Hitokabe and Kesengawa masses, but less than one in those from the Hirota mass. Similar hornblendes poor in $\mathrm{Al}$ occur as the reaction products of primary pyroxene in shallow intrusives accompanying cauldron subsidence such as the Ben Nevis complex (Haslam, 1968) and the Tamagawa plutonic complex (Murakami, 1969). Generally, in hornblendes from each mass in this district, increasing amounts of tetrahedral $\mathrm{Al}$ are balanced both by increased entry of alkalies into the $\mathrm{A}$ site and by substitution of tri- 

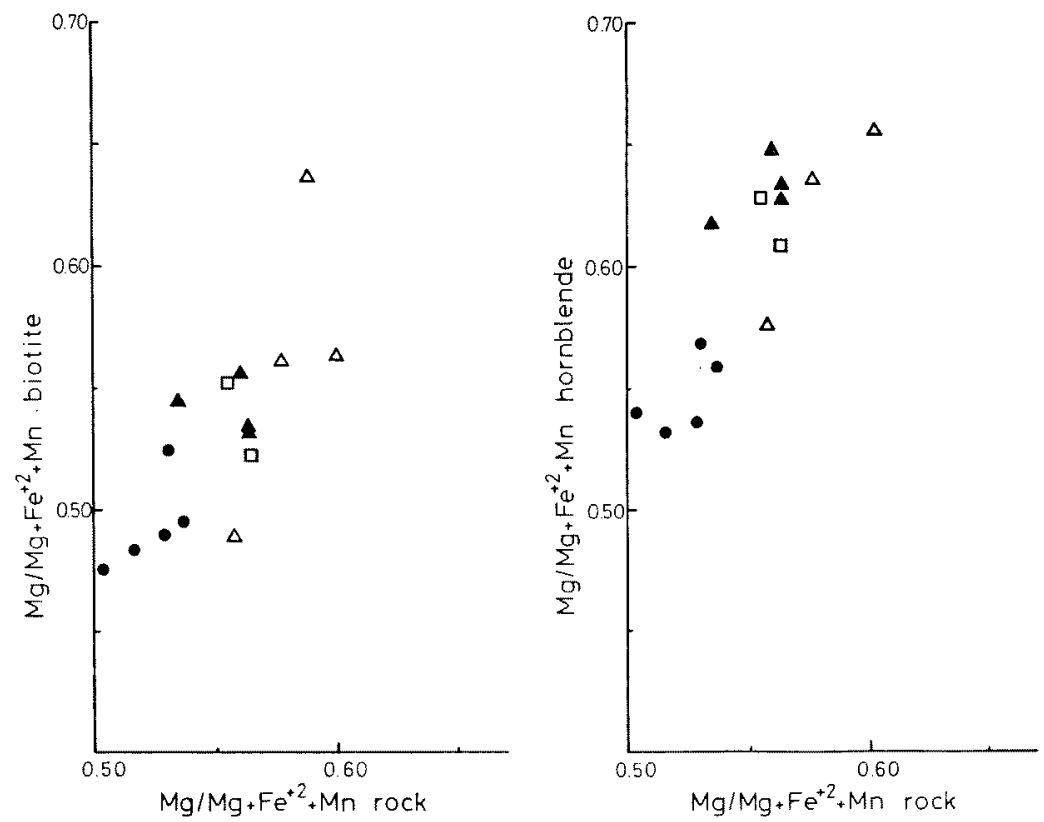

Fig. 6. Relationship between $\mathrm{Mg} / \mathrm{Mg}+\mathrm{Fe}^{+2}+\mathrm{Mn}$ of the minerals and those of their host rocks.

and quadri-valent cations in the octahedral $\mathrm{Y}$ site. Ca per formula unit is $1.8-2.0$ in all granitic masses in this district.

$\mathrm{The} \mathrm{Mg} /\left(\mathrm{Mg}+\mathrm{Fe}^{+2}+\mathrm{Mn}\right)$ ratios of biotites and hornblendes are practically correlated with those of their host rocks as shown in Fig. 6.

The relation of $\mathrm{Fe}^{+3}-\mathrm{Fe}^{+2}-\mathrm{Mg}$ contents in coexisting biotites and hornblendes is shown in Fig. 7. It is clear that all hornblendes are richer in $\mathrm{Fe}^{+3}$ than coexisting biotites, and that the composition of most of biotites is defined by oxygen fugacities equal to or slightly higher than those of $\mathrm{Ni}-\mathrm{NiO}$ buffer estimated by Wones and Eugster (1965). All biotites associate with Kfeldspar and magnetite, thus the oxygen fugacities of granitic magmas in the Kitakami mountains were approximately constant. However, in the Tono granitic mass, oxygen fugacity increased slightly with cooling, therefore, biotites tend to be slightly rich in $\mathrm{Mg}$ with increasing D.I, of the host rocks.

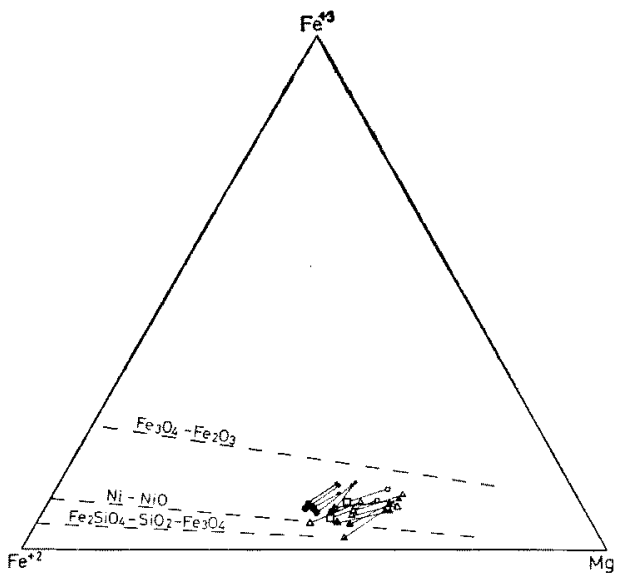

Fig. 7. $\mathrm{Fe}^{+3}-\mathrm{Fe}^{+2}-\mathrm{Mg}$ diagram of coexisting biotites and hornblendes. Large symbols are biotites and small symbols are hornblendes. Dashed lines represent compositions of 'buffered' biotites in the ternary system $\mathrm{KFe}_{3}{ }^{+3} \mathrm{AlSi}_{3} \mathrm{O}_{12} \mathrm{H}_{-1-}$ $\mathrm{KFe}_{3}{ }^{+2} \mathrm{AlSi}_{3} \mathrm{O}_{10}(\mathrm{OH})_{2^{-}}-\mathrm{KMg}_{3} \mathrm{AlSi}_{3} \mathrm{O}_{10}$ $(\mathrm{OH})_{2}$ estimated by Wones \& Eugster (1965). 


\begin{tabular}{|c|c|c|c|c|c|}
\hline \multicolumn{2}{|c|}{$\stackrel{\dot{u}}{\dot{z}}$} & $\stackrel{0}{0}$ & 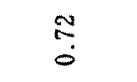 & $\stackrel{9}{:}$ & $\begin{array}{l}8 \\
0 \\
0\end{array}$ \\
\hline \multicolumn{2}{|c|}{ 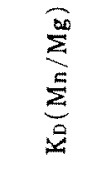 } & $\begin{array}{lllll}0 & 0 & 0 & 0 & 0 \\
0 & 0 & 0 & 0 \\
0 & 0 & 0 & 0 & 0\end{array}$ & $\begin{array}{lll}8 & 0 & 0 \\
0 & 0 & 2 \\
0 & 0 & 0\end{array}$ & $\begin{array}{ll}\ddot{0} & 0 \\
0 & 0 \\
0 & 0\end{array}$ & $\begin{array}{llll}2 & 0 & 0 & 0 \\
0 & 0 & 0 \\
0 & 0 & 0 & 0\end{array}$ \\
\hline \multicolumn{2}{|c|}{$\dot{\Delta}$} & $\stackrel{9}{2}$ & $\begin{array}{l}8 \\
8 \\
0\end{array}$ & $\stackrel{?}{0}$ & $\begin{array}{l}0 \\
0\end{array}$ \\
\hline \multicolumn{2}{|c|}{ 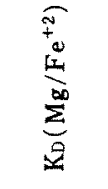 } & $\begin{array}{lllll}\pi & 0 & 0 & 9 & \overline{0} \\
0 & 0 & 0 & 0 \\
0 & 0 & 0 & 0 & 0\end{array}$ & 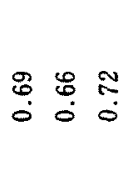 & $\begin{array}{l}\not \\
\stackrel{0}{0} \\
0\end{array}$ & 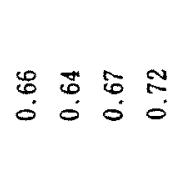 \\
\hline \multirow{3}{*}{ 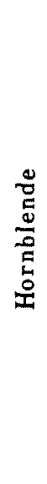 } & $\sum_{\sum}^{\infty}$ & 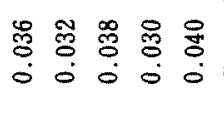 & 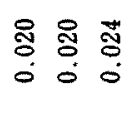 & 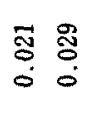 & 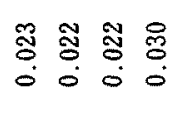 \\
\hline & $\begin{array}{l}+ \\
+ \\
L \\
+ \\
+ \\
\sum_{0}^{\infty} \\
\sum\end{array}$ & 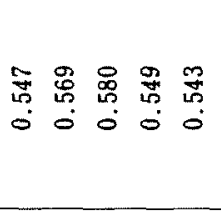 & 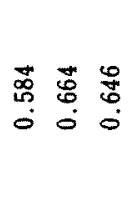 & 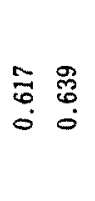 & 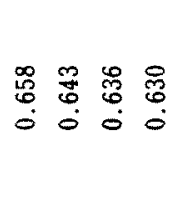 \\
\hline & $\underbrace{+\infty}_{\sum}$ & 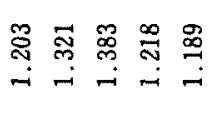 & 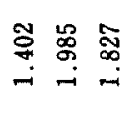 & $\underset{0}{\mathbb{6}} \underset{-}{\mathbb{Z}}$ & 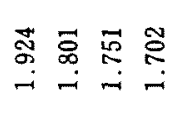 \\
\hline \multirow{3}{*}{ 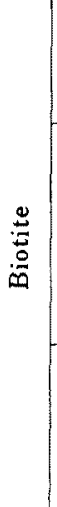 } & $\sum_{\sum}^{\infty}$ & 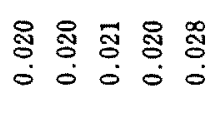 & $\begin{array}{lll}0 & m & 9 \\
0 & 3 & 0 \\
0 & 0 & 0 \\
0 & 0 & 0\end{array}$ & $\begin{array}{l}\vdots \\
\vdots \\
0 \\
0\end{array}$ & $\begin{array}{llll}\frac{n}{0} & m & \Xi & 0 \\
0 & 0 \\
0 & 0 & 0 & 0\end{array}$ \\
\hline & 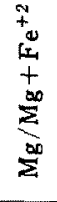 & 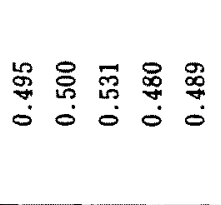 & 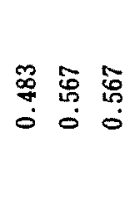 & 总: & 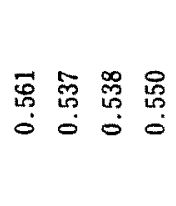 \\
\hline & 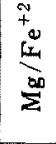 & 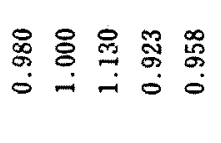 & 空总疍 & 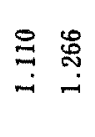 & 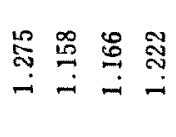 \\
\hline \multicolumn{2}{|c|}{$\dot{z}$} & $\because$ N $N 00$ & 主突总 & $\overrightarrow{5}$ & 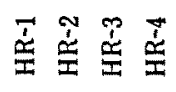 \\
\hline & & 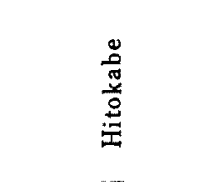 & $\stackrel{\circ}{\stackrel{\circ}{\circ}}$ & 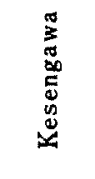 & 苋 \\
\hline
\end{tabular}


5. Distribution of $\mathrm{Fe}^{+2}, \mathrm{Mg}_{\mathrm{g}}$ AND Mn in Coexisting Biotites AND HORNBLENDES

Most of the granitic rocks in the present district have coexisting biotites and hornblendes. It is ambiguous whether these two minerals were equilibrated or not in the host rocks, but the fact that they do not show any reaction texture with each other suggests the possibility that they have crystallized simultaneously. Biotites and hornblendes are assumed at present to have attained equilibrium to some extent.

The distribution coefficients for $\mathrm{Mg}$, $\mathrm{Fe}^{+2}$ and $\mathrm{Mn}$ in coexisting biotite and hornblende are expressed as

$$
\begin{aligned}
\mathrm{K}_{\mathrm{D}}\left(\mathrm{Mg} / \mathrm{Fe}^{+2}\right)_{(\text {bio/hor }}=\left(\mathrm{Mg} / \mathrm{Fe}^{+2}\right)_{\text {bio }} \\
\div\left(\mathrm{Mg} / \mathrm{Fe}^{+2}\right)_{\text {hor }} \text { and } \mathrm{K}_{\mathrm{D}}(\mathrm{Mn} / \mathrm{Mg})_{\text {(bio/hor) }} \\
=(\mathrm{Mn} / \mathrm{Mg})_{\text {bio }} \div(\mathrm{Mn} / \mathrm{Mg})_{\text {hor }} \\
\quad \text { The } \mathrm{Mg} / \mathrm{Fe}^{+2}, \mathrm{Mg} / \mathrm{Mg}+\mathrm{Fe}^{+2} \text { and } \mathrm{Mn} / \mathrm{Mg}
\end{aligned}
$$
ratios and $\mathrm{K}_{\mathrm{D}}$ of coexisting biotite-horn blende pairs are shown in Table 4 . It is clear from these data that $K_{D}$ values for hornblende-biotite pairs are approximately constant in each granitic mass, that is, $\mathrm{K}_{\mathrm{D}}=$ 0.79 in the Hitokabe mass, 0.70 in the Kesengawa mass, 0.69 in the Tono mass and 0.67 in the Hirota mass. The distribution of $\mathrm{Mg} / \mathrm{Fe}^{+2}$ between biotites and hornblendes in each granitic mass is shown in Fig. 8.

The average $K_{D}$ values for coexisting biotite-hornblende in granitic rocks from various districts are given below; $K_{D}=0.83$ and 0.82 in the Garabal Hill-Glen Fyne complex and the Morvern-Strontian complex respectively (Nockolds and Mitchell, 1948), $\mathrm{K}_{\mathrm{D}}=0.82$ in the Southern California batholith (Larsen and Draisin, 1950), $\mathrm{K}_{\mathrm{D}}=0.77$, 0.81 and 0.64 in the rocks of the youngest age, the intermediate age and the oldest age from the Central Sierra Nevada batholith, respectively (Dodge et al., 1968 and 1969), $\mathrm{K}_{\mathrm{D}}=0.65$ in the zoned plutons of Northern Sierra Nevada (Hietanen, 1971), $\mathrm{K}_{\mathrm{D}}=0.56$ in the Ben Nevis complex (Haslam, 1968), $K_{D}$ $=0.92$ in the granitic rocks near the San Andreas Fault (Dodge and Ross, 1971), $\mathrm{K}_{\mathrm{D}}$ $=0.79$ in the rocks of amphibolite-quartz diorite series from the Takanuki district (Ogura, 1959), $\mathrm{K}_{\mathrm{D}}=0.64$ in the Orikabe granodioritic mass, Kitakami mountains (Kato, 1972), and $K_{D}=0.93$ in the Ryoke granitic rocks of the Takato district, Central Japan (Kanisawa, unpublished data). Mueller (1963) posed an interesting question whether equilibrium can be established or not with respect to $\mathrm{Fe}^{+2}$ and $\mathrm{Mg}$ when the coexisting plagioclase is zoned. According

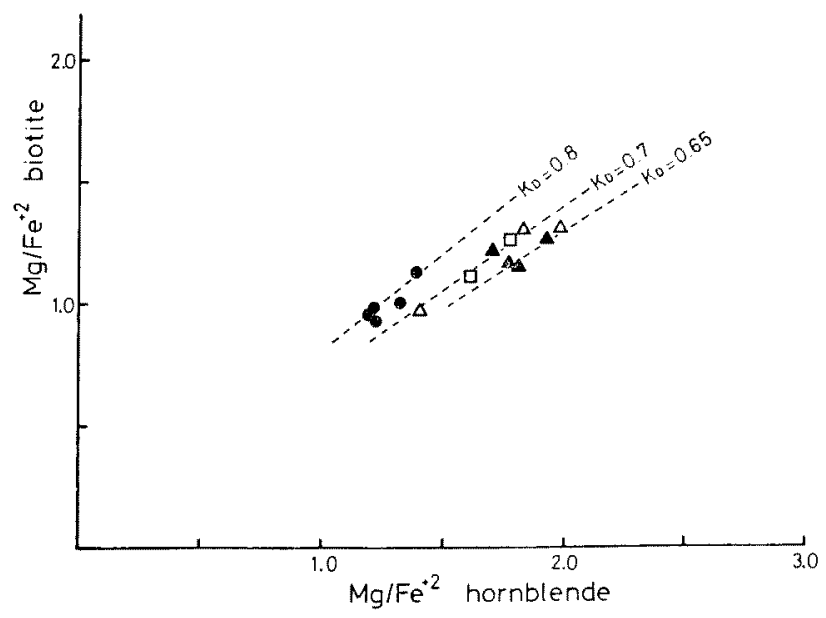

Fig. 8. Distribution of $\mathrm{Mg}-\mathrm{Fe}^{+2}$ between coexisting biotite and hornblende. 
to Mueller, existence of such a plagioclase showing compositional zoning indicates kinetic situation unfavourable for equilibrium. Biotite-hornblende pairs of granitic rocks from the Kitakami mountains are all associated with strongly zoned plagioclase, however, $K_{D}$ values for biotite-hornblende pairs are approximately constant in each granitic mass in the Kitakami mountains and other districts. This fact shows that biotite-hornblende pairs were equilibrated on the $\mathrm{Mg}$ $\mathrm{Fe}^{+2}$ distribution to some extent even in condition that zoned plagioclase crystallized in granitic magma.

Distribution coefficients of $\mathrm{Mg}-\mathrm{Fe}^{+2}$ for biotite-hornblende pairs from areas of different metamorphic facies do not show any systematic variation with the difference of metamorphic facies (Leelanandam, 1970). The $K_{D}$ values for biotite-hornblende pairs from granitic rocks are also difficult to correlate simply with PT-condition. The variation in $K_{D}$ values for coexisting biotitehornblende pairs either from magmatic or from metamorphic rocks, could be influenced largely by the differing mineralogy and chemical composition of the host rocks, the multivariant nature of the minerals, and to the chemicomechanical effects consequent on the regional and environmental influences characteristic of individual terrains (Mueller; 1963, Saxena; 1968, Leelanandam; 1970). $\mathrm{K}_{\mathrm{D}}$ values of $\mathrm{Mg}^{-\mathrm{Fe}^{+2}}$ for coexisting biotite-hornblende pairs in granitic rocks from the Kitakami mountains depend largely upon $\mathrm{Al}$ contents in these minerals, because biotites and hornblendes from the Hitokabe mass rich in tetrahedral $\mathrm{Al}$ have larger $\mathrm{K}_{\mathrm{D}}$ value, but those from the Hirota mass poor in tetrahedral and octahedral $\mathrm{Al}$ have smaller $K_{D}$ value.

$\mathrm{Mn}-\mathrm{Mg}$ distribution between coexisting biotite-hornblende pairs in granitic rocks from the Kitakami mountains are indicated in Table 4 and Fig. 9. $\mathrm{K}_{\mathrm{D}}(\mathrm{Mn} / \mathrm{Mg})$ values vary from 0.81 to 0.53 and average value in the Kesengawa mass is the largest, while that in the Hirota mass is the smallest. Recently, Greenland et al. (1968) has shown that the distribution of Mn between coexisting biotite and hornblende reflects exchange at subsolidus temperatures rather than initial crystallization temperatures and that

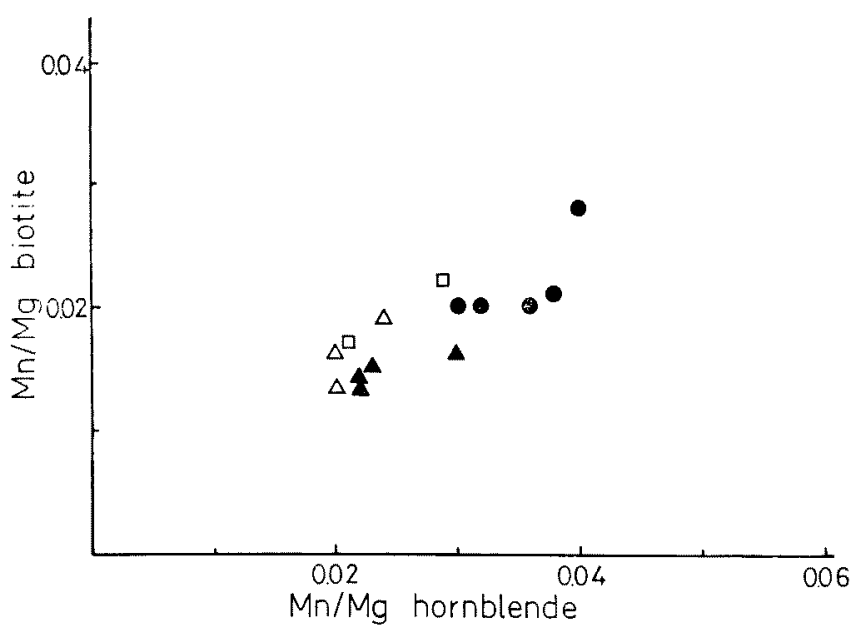

Fig. 9. Distribution of $\mathrm{Mn}-\mathrm{Mg}$ between coexisting biotite and hornblende. 
there is a positive correlation of $\mathrm{K}_{\mathrm{D}}$ with $\mathrm{TiO}_{2}$ content of biotite for biotite-hornblende pairs from the Southern California and Sierra Nevada batholiths. However, in the granitic rocks of the district, it is difficult to investigate whether the concepts of Greenland et al. can be applicable or not, and the $K_{D}(\mathrm{Mn} / \mathrm{Mg})$ values for biotite-hornblende pairs is independent of $\mathrm{TiO}_{2}$ content of biotite.

\section{SUMMARY}

Biotites and hornblendes in the Hitokabe, Tono, Kesengawa and Hirota masses were chemically analyzed. Compositions of most biotites are rich in Si, thus they are close to phlogopite-annite series. Generally, biotites become richer in siderophyllite-eastonite molecule with increasing differentiation index of their host rocks. Biotites in the Hirota mass are rich in $\mathrm{TiO}_{2}$ and poor in $\mathrm{Al}_{2} \mathrm{O}_{3}$. Hornblendes of the Hitokabe, Tono and Kesengawa masses are similar in composition one another, while those of the Hirota mass are poorer in $\mathrm{Al}^{\mathrm{Iv}}, \mathrm{Na}+\mathrm{K}$, and $\mathrm{Al}^{\mathrm{VI}}+\mathrm{Ti}+\mathrm{Fe}^{+3}$ and richer in $\mathrm{Si}$ than those of the other masses. Generally, substitution of $\mathrm{Si}$ by tetrahedral $\mathrm{Al}$ in hornblendes of granitic rocks from the district are balanced by $\mathrm{Na}+\mathrm{K}$ in the $\mathrm{A}$ site and $\mathrm{Fe}^{+3}$, $\mathrm{Al}^{\mathrm{vi}}$ and $\mathrm{Ti}$ ions in the $\mathrm{Y}$ site. The $\mathrm{Mg}-\mathrm{Fe}$ distribution coefficients for coexisting biotite-hornblende pairs are approximately constant in each granitic mass, that is, $\mathbf{K}_{\mathbf{D}}$ $\left(\mathrm{Mg} / \mathrm{Fe}^{+2}\right)$ for biotite/hornblende is 0.79 in the Hitokabe mass, 0.70 in the Kesengawa mass, 0.69 in the Tono mass, and 0.67 in the Hirota mass. The variation of $K_{D}$ among each granitic mass depends largely upon $\mathrm{Al}$ contents in these minerals.

\section{REFERENCES}

Deer, W.A., Howie, R.A. and Zussman, J. (1963a),
Rock forming minerals, vol. 2; Chain silicates, Longmans, London.

$\longrightarrow$, - and $\longrightarrow$ (1963b), Rock forming minerals, vol. 3; Sheet silicates, Longmans, London.

Dodge, F.C.W., Papike, J.J. and Mays, R.E. (1968), Hornblendes from granitic rocks of the Central Sierra Nevada batholith, California, Jour. Petrol., 9, 378-410.

-, Smith, V.C. and Mays, R.E. (1969), Biotites from granitic rocks of the Central Sierra Nevada batholith, California, Jour. Petrol., 10, 250-271.

—, and Ross, D.C. (1971), Coexisting hornblendes and biotites from granitic rocks near the San Andreas fault, California, Jour. Geol., 79, $158-172$.

Greenland, L.P., Gottfried, D. and Tilling, R.I. (1968), Distribution of manganese between coexisting biotite and hornblende in plutonic rocks, Geochim. Cosmochim. Acta, 32, 11491163.

Haslam, H.W. (1968), The crystallization of intermediate and acid magmas at Ben Nevis, Sctotland, Jour. Petrol., 9, 84-104.

Hietanen, A. (1971), Distribution of elements in biotite-hornblende pairs and in an orthopyroxene-clinopyroxene pair from zoned plutons, Northern Sierra Nevada, California, Contrib. Mineral. Petrology, 30, 161-176.

Kanisawa, S. (1969), On the Hitokabe granodioritic mass, Kitakami Mountainland, Jour. Japan, Assoc. Min. Petr. Econ. Geol., 62, 275 288 (in Japanese with English abstract).

-. (1972), Optical properties of plagioclases in some granitic rocks, Kitakami mountains, Northern Japan, Jour. Geol. Soc. Japan, 78, 301-307.

Katada, M., Onuki, H., Kato, Y., Kanisawa, S., Ono, C. and Yoshii, M. (1971), Zonal arrangement of the Cretaceous granitic rocks, Kitakami mountainland, Jour. Japan. Assoc. Min. Petr. Econ. Geol, 65, 230-245 (in Japanese with English abstract).

Kato, Y. (1972), Petrology of the Orikabe granitic body, Kitakami mountainland, Jour. Japan. Assoc. Min. Petr. Econ. Geol., 67, 50-59, (in Japanese with English abstract).

Kawano, Y. and Ueda, Y. (1965), K-A dating on the igneous rocks in Japan (II) - Granitic rocks in Kitakami massif, Jour. Japan, Assoc. Min. Petr. Econ. Geol, 53, 143-154 (in Japanese with English abstract).

Larsen, E.S., Jr. and Draisin, W.M. (1950), Composition of the minerals in the rocks of the Southern California batholith, Rep. 18th Int. Geol. Congr. Great Britain, 1948, pt. 2, 66-79. 
Leake, B.E. (1968), A catalog of analyzed calciferous and subcalciferous amphiboles together with their nomenclature and associated minerals, Geol. Soc. Am. Special Paper, no. 98.

Leelanandam, C. (1970), Chemical mineralogy of hornblendes and biotites from the charnockitic rocks of Kondapalli, India, Jour. Petrol., 11, 475-505.

Mueller, R.F. (1963), Interaction of chemistry and mechanics in magmatism, Jour. Geol., 71, 759772.

Murakami, N. (1969), Two contrastive trends of evolution of biotite in granitic rocks, Jour. Japan. Assoc. Min. Petr. Econ. Geol., 62, 223248.

Nockolds, S.R. (1948), The relation between chemical composition and paragenesis in the biotite micas of igneous rocks, Am. Jour. Sci., $245,401-420$.

- -, and Mitchell, R.L. (1948), The geoche- mistry of some Caledonian plutonic rocks: a study in the relationship between the major and trace elements of igneous rocks and their minerals, Trans. Royal Soc. Edinb., 61, 533575.

Ogura, Y. (1959), On the granitization of some basic rocks of the Gosaisho-Takanuki district, Southern Abukuma plateau, Japan, Japan. Jour. Geol. Geogr., 29, 171-198.

Onuki, Y. (1969), Geology of the Kitakami Massif, Northeast Japan, Tohoku Univ. Inst. Geol. Pal. Contr., no. 69, 1-239 (in Japanese with English abstract).

Saxena, S.K. (1968), Distribution of elements between coexisting minerals and the nature of solid solution in garnet, Am. Mineral., 53, 9941014.

Wones, D.R. and Eugster, H.P. (1965), Stability of biotite: experiment, theory, and application, Am. Mineral., 50, 1228-1272.

\title{
南部北上山地の 2,3 の花崗岩体中の共存する黒雲母と角閃石
}

\author{
蟹沢聰史 \\ 北上山地の人首・遠野・気仙川および広田岩体中の共存する黒雲母と角閏石について化学分析を行なった。 \\ 黒雲母は phlogopite-annite series 飞近い組成をもつものが大部分であるが、岩石の D.I. が大きくなるにつ \\ れて, siderophyllite-eastonite に近い組成に変る。角閃石については，人首・遠野·気仙川の各岩体のものは \\ 互に似た化学組成を示寸が，広田岩体のものは $\mathrm{Al}, \mathrm{Na}+\mathrm{K}$ にとばしく，Si にとむ。人首・遠野・気仙川・広 \\ 田岩体中で其存寸る黒雲母と角関石の $\mathrm{K}_{\mathrm{D}}\left(\mathrm{Mg} / \mathrm{Fe}^{+2}\right)$ は各岩体じとにはぼ一定で，そ机ぞれ $0.79,0.69,0.70$ ， \\ および 0.67 である。KDの小さい岩体の角閃石は一般に Al にとばしい。
}

